\title{
Teenagers' Knowledge and Perception about The Staple Food Diversity to Describe Daily Eating Habit
}

\author{
Familia Novita Simanjuntak \\ Department of Chemistry Education \\ Christian University of Indonesia \\ DKI Jakarta, Indonesia \\ familia.novita@gmail.com
}

\begin{abstract}
Daily eating habit of teenagers is usually described by knowledge and perception based on their family culture/heritage or education experience or social life. This research studies about how the knowledge and perception of teenagers describe their daily eating habit. Staple food is a group of food to reach the balance nutrition, which is consumed regularly in certain portion to obtain the carbohydrate as the source of energy. Indonesia has 77 kinds of staple food as the potential sources of carbohydrate such as cereal plants (paddy, sorghum), roots (garut - Maranta arundinacea, ganyong - Canna discolor, gembili - Dioscorea esculenta), and fruits (sukun/bread fruit, banana). This research uses the quantitative approach to analyze the data. Data is randomly gathered from students of High School YADIKA 11, West Java. The results of this research consist of students' knowledge and perception of staple food. The students' knowledge about staple food is 67 percent for items, 55 percent for kinds, 65 percent for provenance, 73 percent for definition, and 88 percent for benefits. However, the knowledge about Indonesian endemic staple food is only 32 percent. The students' perception of staple food by giving the score based on the choice $(5$ for rice and 3 for corn, cassava, potato, sweet potato and banana), taste ( 5 for rice and 3 for corn, cassava, potato, and sweet potato) and appearance ( 5 for rice and 3 for corn, cassava, potato, sweet and potato). The students have low level of knowledge about Indonesian endemic staple food. This means that teenagers' daily eating habit is only described by 6 kinds of staple food.
\end{abstract}

Keywords-teenagers; knowledge and perception; staple food; diversity; eating habit

\section{INTRODUCTION}

Daily eating habit of teenagers is usually described by knowledge and perception based on their family culture/heritage [1]-[3] or education experience or social life [4]-[7]. Eating habit refers to the way and reason of eating, which food that should be chosen to eat, and how to process the food before eating [8]. Pereira-Santos, et.al. [9] Identify four pattern of eating habit on students they are traditional, exam days, end of semester and anxiety. The ingredients of food within the eating habit determine the four patterns. Traditional eating pattern consists of roots/tubers, legumes, dairy products, meat, eggs, fruit/natural juice and vegetables. Exam day eating pattern is made up of breads/cereals, sausages and artificial beverage. End of semester eating pattern is characterized predominantly by candy/sugar and snacks. Anxiety eating pattern is made up of coffee/tea and fats. Eating habit on teenagers influences the nutrition intake especially carbohydrate as the source of energy to do their daily activities. Food and nutrition guidelines for healthy teenagers (New Zealand, 1998) states that a constant supply of energy maintains the function of all body and consuming one gram carbohydrate provides $17 \mathrm{~kJ}$ of energy, about half the energy intake for teenagers boys and girls. Astrup [10] defines that the source of carbohydrate is important for diet's effect on body weight by increasing the satiating and thermo genic effect of ad lib (as you desire or at one's pleasure) diets which facilitate weight loss and maintenance.

Indonesia has 77 kinds of staple food as the potential sources of carbohydrate such as cereal plants (paddy, sorghum), roots (garut, ganyong, gembili), and fruits (sukun/bread fruit, banana), but, up to now, Indonesia only know paddy as the common staple food [11]. Post green revolution era (the era when crop cultivation used high dose synthetic fertilizer and pesticide to produce maximum harvest), over exploitation on paddy field to accomplish the crop self-sufficient country had increased the quantity of unfertile soil especially in Java and Sumatera. The increased infertile soil pushed the Indonesian government to provide another crops as the alternative staple food to supply sustainable energy intake for the society especially infants and teenagers.

Eating habit includes staple food preferences on teenagers is influenced by mother as the person who is responsible to provide sufficient energy for whole family member or father as the head of family who is strongly doing the patrimonial eating habit. In social life, teenagers' preferences on staple food is also influenced by peers [12]. This research studies about how the knowledge and perception of teenagers describe their daily eating habit. The hypothesis of this research is teenagers have various staple food preferences and consume diverse staple food.

\section{REVIEW OF LITERATURES}

\section{A. Teenagers' Eating Habit}

Eating habit can be formed by learning process through the observation, experiment and repetition [13]. The initial process of eating habit on staple food is observation. People observe all kinds of food, which are the best staple food to supply the sufficient energy based on their needs and age. Further process continues to determine the staple food, which 
are able to increase the satiating, and thermogenic effect to facilitate weight loss and maintenance [10]. The selected staple food will be the daily preferences as the source of energy supply. Different with adult, learning process of forming eating habit on adolescent is influenced by mother as the person who is responsible to provide sufficient energy for completely family member or father as the head of family who is strongly doing the patrimonial eating habit. In social life, adolescent's preferences on staple food is also influenced by peers [12].

Ganasegeran, et.al. [14] defines that eating habit is associated to socio-demographic characteristic and psychological factors. The socio-demographic characteristic associated to eating habit consist of gender, age, ethnicity, mother's education level, father's education level, monthly household income, living arrangement, body mass index, mother working, smoking, alcohol and regular exercise. The psychological factors that are associated to eating habit related to feeling such as feeling lonely, feeling complete, feeling satisfy by hurting stomach with over eating, feeling upset or nervous, feeling bored and feeling happy.

\section{B. Indonesian Government Support on Teenagers' Eating Habit}

Indonesian government through Ministry of Health Regulation No. 41 Year 2014 on Guidelines for Balanced Nutrition supports the energy intake from staple food to achieve the balanced nutrition. Furthermore, Indonesian government leads the society to consume food diversity, especially staple food, as regulated in Laws of The Republic Indonesia No. 18 Year 2012 on Food Article No. 41. Food diversity consumption will lead the increasing of various food availability based on local resources potency to achieve food security.

Food security become common issues since the infertile soil increasing while population keeps growing, in other words, population is growing significantly meanwhile the land (natural) resources is decreasing. World Food Summit year 1974 defined food security as the availability at all times of adequate world food supplies of basic foodstuffs to sustain a steady expansion of food consumption and to offset fluctuations in production and prices. FAO (1983) expands the concept of food security include securing access by vulnerable people to available supplies or ensuring that all people at all times have both physical and economic access to the basic food that they need. The purpose of food security is food access for an active and healthy life.

Indonesia as a country whose climate humid all years has the largest biodiversity in South East Asia so that food security can be done properly by promoting food diversity consumption, especially to teenagers. Food diversity consumption on teenagers will be able to lead balance eating and mental health [15]. Consuming staple food as carbohydrate supply on teenagers also aims to reach the sufficient nutrition intake includes protein and fat that are associated to facilitate weight loss and maintenance. Astrup [10] states that carbohydrate consumption can increase sensation of fullness and enhance satiety so that are able to support the beneficial effects of a fat-reduced diet from ample fiber and completely grain foods.

\section{Food Factors Affecting Teenagers' Mental Health}

Teenagers refer to the persons between 13 and 19 years old. Moersintowarti [16] defines that teenage is a period of life between child age and fully adult which has physically maturity. Food intake is one of factors affecting to teenagers' mental health [14] but getting teenagers to eat healthier is not easy. Oddy, et.al. [17] found that poorer mental health outcomes are associated to Western dietary pattern, a diet that is high in red and processed meats, take-out, and sugary and refined foods, and better mental health outcomes are found in people who had a higher intake of fresh fruit and leafy green vegetables.

Nutrition scientists of Regional Research Institute for Human Services - Portland State University recommend rainbow diet and Omega-3 food sources to maintain better mental health on teenagers as shown in Picture 1.

\begin{tabular}{|l|l|l|}
\multicolumn{1}{|c|}{$\begin{array}{c}\text { Food or } \\
\text { Supplement }\end{array}$} & \multicolumn{1}{c|}{$\begin{array}{c}\text { Improvements in Mental } \\
\text { Health Conditions }\end{array}$} & \multicolumn{1}{c|}{ Good Sources } \\
\hline $\begin{array}{l}\text { Fish and Fish Oil; } \\
\text { Omega-3 Fatty Acids }\end{array}$ & Psychosis & $\begin{array}{l}\text { Fish oil supplements containing omega-3 fatty acids or } \\
\text { cold deep seawater fish such as salmon; flax seeds; and } \\
\text { walnuts. }\end{array}$ \\
\hline Vitamin D & $\begin{array}{l}\text { Cognitive Impairment, } \\
\text { depression, bipolar disorder, } \\
\text { schizophrenia }\end{array}$ & $\begin{array}{l}\text { Vitamin D dietary supplements; limited amounts of } \\
\text { unprotected exposure to natural sunlight (avoid burning); } \\
\text { fatty fish such as salmon, tuna, and mackerel; and vitamin } \\
\text { D fortified foods such as orange juice, milk, and yogurt. }\end{array}$ \\
\hline $\begin{array}{l}\text { High intake of fresh fruit, } \\
\text { leafy greens, and other } \\
\text { vegetables }\end{array}$ & $\begin{array}{l}\text { General positive mental health } \\
\text { outcomes }\end{array}$ & $\begin{array}{l}\text { Apple slices, oranges, berries, bananas, kale chips, collard } \\
\text { greens, spinach, tomatoes, carrots, etc. }\end{array}$ \\
\hline
\end{tabular}

Picture 1. Rainbow Diet and Omega-3 Food Source [18]

\section{METHOD}

\section{A. Study Setting and Population}

This study aims to describe the eating habit of teenager based on their knowledge and perception on staple food as the source of daily energy intake. The observed teenagers are 121 students of High School YADIKA 11, West Java and age is between 15 and 16 years old. To get the information of knowledge, students answered questions about staple food items and kinds of common and Indonesian endemic (names of raw food and cooked), provenance (food source), definition and benefit of staple food consuming. The perception of students on staple food is informed by filling the questionnaire about choice (preferences), taste and appearance of staple food.

\section{B. Instruments}

This research uses two kinds of questionnaire to gather information about knowledge and perception on staple food. First questionnaire for knowledge description is combination questionnaire (close and open questionnaire) consists of 35 questions. The second is likert scale questionnaire that uses five response scores-categories to represent the perception on 
staple food. The categories of five scores-responses that are used in likert scale questionnaire as listed in Table 1.

TABLE 1. FIVE RESPONSES OF LIKERT SCALE QUESTIONNAIRE

\begin{tabular}{|l|c|c|}
\hline $\begin{array}{c}\text { Score - } \\
\text { Category }\end{array}$ & $\begin{array}{c}\text { Taste and } \\
\text { Appearance }\end{array}$ & $\begin{array}{c}\text { Choice } \\
\text { (days a week of consumption) }\end{array}$ \\
\hline $\mathbf{5}-$ SL & Always & 7 \\
\hline $\mathbf{4}-$ SR & Often & $5-6$ \\
\hline $\mathbf{3}-$ KD & Sometimes & $3-4$ \\
\hline $\mathbf{2}-$ J & Rare & $1-2$ \\
\hline $\mathbf{1}-$ TP & Never & 0 \\
\hline
\end{tabular}

The students also mention their parents' culture of origin. Parents' culture of origin, especially father's, is important to be the consideration of students' answers about staple food that are familiar to them or consumed every day in family.

\section{Data Analysis}

Data is analyzed using descriptive statistic. First, students answered the questionnaire about knowledge, then the answers are gathered and analyze by descriptive statistic. Second, the result of first questionnaire analyze was used as the data base to determine the choice, taste and appearance of staple food in the second questionnaire to gather data about perception on staple food. The answers of the second questionnaire are also gathered and descriptively analyze.

Further, this study compared the data from the first and second questionnaires with the data about fathers' culture origin of each student. This study did not analyze the correlation between students' knowledge, perception and fathers' culture of origin.

\section{RESUlt AND DisCUSSION}

Knowledge about staple food is determined by the correct answers of each student on the combination questionnaire. Close questionnaire consist of questions about items, kinds, Indonesian endemic, provenance, definition and benefit of eating. Further, students mentioned other items and kinds of staple food such as fried rice, bread and noodle as the answers in open questionnaire based on their daily eating in family, social life and knowledge. However, there were 15 students mentioned the name of food which are not staple food such as tempe, tofu, dish, and vegetable, means that these students have misconception about the definition and benefit of eating staple food. The description of knowledge on staple food as listed in Table 2.

TABLE 2. DESCRIPTION OF KNOWLEDGE ON STAPLE FOOD

\begin{tabular}{|c|c|c|c|c|}
\hline No. & $\begin{array}{c}\text { Knowledge on } \\
\text { staple food }\end{array}$ & $\begin{array}{c}\text { Number of } \\
\text { Correct } \\
\text { Answer }\end{array}$ & $\begin{array}{c}\text { Number of } \\
\text { Answers }\end{array}$ & $\begin{array}{c}\text { \% of } \\
\text { Correct } \\
\text { Answer }\end{array}$ \\
\hline 1 & Items & 408 & 605 & $67 \%$ \\
\hline 2 & Kinds & 201 & 363 & $55 \%$ \\
\hline 3 & $\begin{array}{c}\text { Indonesian } \\
\text { endemic }\end{array}$ & 346 & 1089 & $32 \%$ \\
\hline 4 & Provenance & 313 & 484 & $65 \%$ \\
\hline 5 & Definition & 265 & 363 & $73 \%$ \\
\hline 6 & Benefit & 321 & 363 & $88 \%$ \\
\hline
\end{tabular}

The items refers to the name of raw staple food such as rice, corn, sweet potato, cassava, potato, jewawut, gembili, sago, ganyong, and banana, while, the kinds refers to the name of cooked staple food i.e. porridge, rasi, tiwul, millet porridge, papeda, etc. The provenance refers to the name of raw food for cooked staple food such as rice for porridge, corn for rasi, cassava for tiwul, jewawut - Setaria italica for millet porridge, sago for papeda, etc.

Table 2. Shows that the students have a proper knowledge about staple food they are $67 \%$ for items, $55 \%$ for kinds, $65 \%$ for provenance, $73 \%$ for definition, and $88 \%$ for benefits. However, the students have poor knowledge about Indonesian endemic staple food is only $32 \%$. This description means that students do not have a proper knowledge about Indonesian endemic staple food such as jewawut, gembili, ganyong and sago, so that students do not consume diverse Indonesian endemic staple food.

Indonesian government introduced jewawut, gembili, sago and ganyong as alternative staple food through Minister of Health program named the Movement of Nutrition Awareness year 2012 [19]. Banners about food diversity consumption for active and healthy life are already distributed to school and community health centers (Puskesmas) as shown in Picture 2.

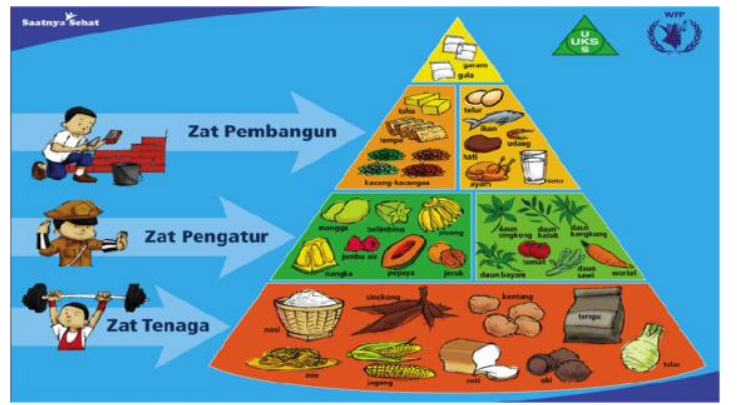

Picture 2. Food Pyramid of Food Diversity (Ministry of Health Socialization about Diverse Food Consumption [18]

The consideration of not consuming diverse Indonesian endemic staple food may because the family of students does not know about it so that they do not consume any at home. The description of students family culture based on their father ethnicity [14] as listed in Table 3.

TABLE 3. THE ETHNICITY OF FATHER AS THE HEAD OF FAMILY

\begin{tabular}{|r|l|r|r|l|c|}
\hline No. & $\begin{array}{c}\text { Ethnicity of } \\
\text { Father }\end{array}$ & Number & No. & $\begin{array}{c}\text { Ethnicity of } \\
\text { Father }\end{array}$ & Number \\
\hline 1. & Batak & 15 & 8. & Bali & 3 \\
\hline 2. & Padang & 3 & 9. & Flores & 7 \\
\hline 3. & Palembang & 2 & 10. & Manado & 5 \\
\hline 4. & Lampung & 3 & 11. & Makassar & 3 \\
\hline 5. & Betawi & 10 & 12. & Bau-bau & 2 \\
\hline 6. & Sunda & 11 & 13. & Ambon & 4 \\
\hline 7. & Jawa & 50 & 14. & Papua & 3 \\
\hline
\end{tabular}

Table 3. Shows that the tribes of Sumatera and Java dominate the ethnicity of students' father as the head of family. Sumatera and Java are the two big islands of Western Indonesia, which are the center of rice fields; this is why most of tribe of Sumatera and Java consume rice as the main staple food. They do not know about other kind of staple food such as sago, jewawut, etc, though sometimes, they consume other staple food such as cassava, corn, banana and sweet potato as snack or dessert.

Further, the students fill the second questionnaire with the checklist mark in column to categorize their perception about 
staple food based on the choice, taste and appearance as listed in Table 4. Table 5. and Table 6.

TABLE 4. STUDENTS' PERCEPTION ABOUT STAPLE FOOD BASED ON CHOICE

\begin{tabular}{|r|l|r|r|r|r|r|r|}
\hline \multirow{2}{*}{ No. } & \multirow{2}{*}{ Items of Staple Food } & \multicolumn{6}{|c|}{ Choices (Preferences) } \\
\cline { 3 - 8 } & & 0-NA & 1-TP & 2-J & 3-KD & 4-SR & 5-SL \\
\hline 1 & Rice & 0 & 0 & 0 & 5 & 7 & 109 \\
\hline 2 & Corn & 0 & 0 & 38 & 67 & 10 & 6 \\
\hline 3 & Cassava & 0 & 2 & 46 & 59 & 11 & 3 \\
\hline 4 & Potato & 0 & 4 & 18 & 62 & 30 & 7 \\
\hline 5 & Sweet potato & 0 & 10 & 49 & 50 & 6 & 6 \\
\hline 6 & Sago & 1 & 40 & 46 & 25 & 8 & 1 \\
\hline 7 & Banana & 0 & 14 & 23 & 40 & 35 & 9 \\
\hline 8 & Taro & 0 & 43 & 53 & 17 & 5 & 3 \\
\hline 9 & Tarul & 2 & 80 & 24 & 9 & 2 & 4 \\
\hline 10 & Wheat & 0 & 23 & 46 & 38 & 8 & 6 \\
\hline 11 & Sorghum & 1 & 98 & 14 & 4 & 2 & 2 \\
\hline 12 & Millet & 2 & 98 & 8 & 6 & 4 & 3 \\
\hline
\end{tabular}

The perception of staple food by choice is categorized by the frequency of consumption. Table 4. shows that students' choices are rice (5-SL) and corn, cassava, potato, sweet potato and banana (3-KD).

TABLE 5. STUDENTS' PERCEPTION ABOUT STAPLE FOOD BASED ON TASTE

\begin{tabular}{|r|l|r|r|r|r|r|r|}
\hline \multirow{2}{*}{ No. } & \multirow{2}{*}{ Items of Staple Food } & \multicolumn{6}{|c|}{ Taste } \\
\cline { 3 - 8 } & & 0-NA & 1-TP & 2-J & 3-KD & 4-SR & 5-SL \\
\hline 1 & Rice & 1 & 2 & 6 & 11 & 32 & 69 \\
\hline 2 & Corn & 2 & 1 & 16 & 46 & 35 & 21 \\
\hline 3 & Cassava & 0 & 1 & 26 & 51 & 26 & 17 \\
\hline 4 & Potato & 0 & 5 & 12 & 41 & 37 & 26 \\
\hline 5 & Sweet potato & 0 & 36 & 45 & 21 & 12 & 7 \\
\hline 6 & Sago & 0 & 7 & 18 & 28 & 34 & 34 \\
\hline 7 & Banana & 0 & 36 & 47 & 20 & 14 & 4 \\
\hline 8 & Taro & 0 & 81 & 24 & 7 & 3 & 6 \\
\hline 9 & Tarul & 0 & 27 & 38 & 33 & 15 & 8 \\
\hline 10 & Wheat & 1 & 88 & 21 & 4 & 5 & 2 \\
\hline 11 & Sorghum & 2 & 89 & 18 & 3 & 2 & 7 \\
\hline 12 & Millet & & & & 46 & 20 & 14 \\
\hline
\end{tabular}

The perception of staple food by taste is categorized by the students' contentment on the items as staple food. Table 5. shows that students' taste score are 5-SL for rice and 3-KD for corn, cassava, potato, and sweet potato. Banana's taste score as staple food get the similar score between 4-SR and 5-SL, means that students like the taste of banana as staple food more than the taste of corn, cassava, potato and sweet potato and similar to the taste of rice.

TABLE 6. STUDENTS' PERCEPTION ABOUT STAPLE FOOD BASED ON APPEARANCE

\begin{tabular}{|r|l|r|r|r|r|r|r|}
\hline \multirow{2}{*}{ No. } & \multirow{2}{*}{ Items of Staple Food } & \multicolumn{6}{|c|}{ Appearance } \\
\cline { 3 - 8 } & & 0-NA & 1-TP & 2-J & 3-KD & 4-SR & 5-SL \\
\hline 1 & Rice & 0 & 15 & 9 & 24 & 29 & 44 \\
\hline 2 & Corn & 0 & 14 & 20 & 41 & 31 & 15 \\
\hline 3 & Cassava & 0 & 13 & 33 & 48 & 20 & 7 \\
\hline 4 & Potato & 0 & 11 & 21 & 43 & 30 & 15 \\
\hline 5 & Sweet potato & 1 & 41 & 37 & 25 & 13 & 2 \\
\hline 6 & Sago & 0 & 13 & 19 & 32 & 32 & 25 \\
\hline 7 & Banana & 0 & 47 & 42 & 16 & 9 & 7 \\
\hline 8 & Taro & 0 & 84 & 15 & 11 & 4 & 7 \\
\hline 9 & Tarul & 1 & 36 & 31 & 28 & 16 & 9 \\
\hline 10 & Wheat & 1 & 95 & 12 & 6 & 4 & 3 \\
\hline 11 & Sorghum & 1 & 98 & 13 & 4 & 2 & 3 \\
\hline 12 & Millet & & & & & & \\
\hline
\end{tabular}

The perception of staple food by appearance is categorized by the students' contentment on the appearance as staple food.
Table 6. shows that students' appearance score are 5-SL for rice and 3-KD for corn, cassava, potato, and sweet potato. Banana's appearance score as staple food get the similar score between 3-KD and 4-SR, means that students like the appearance of banana as staple food similar to the appearance of corn, cassava, potato and sweet potato and less than the appearance of rice.

\section{CONCLUSION}

Eating habit includes staple food preferences on teenagers is influenced by mother as the person who is responsible to provide sufficient energy for whole family member or father as the head of family who is strongly doing the patrimonial eating habit. In social life, teenagers' preferences on staple food is also influenced by peers [12].

The result as listed in Table 2 . shows that students do not have proper knowledge (only 32\%) about Indonesian endemic staple food and there were 15 students have misconception about definition and benefit of eating staple food. Further, Table 3. shows that most of the students' father come from the tribe of Sumatera and Java, the two biggest islands of Western Indonesia which are the centre of rice fields.

The low level of students' knowledge about staple food diversity, only know 6 kinds of staple food they are rice, corn, cassava, potato, sweet potato and banana, may because most of their fathers' ethnicity is from the islands which are centre of rice fields. Furthermore, this condition may lead to the students' perception of staple food by choice, taste and appearance as follows: (1) by choices are rice (5-SL) and corn, cassava, potato, sweet potato and banana (3-KD); (2) taste score are 5-SL for rice and 3-KD for corn, cassava, potato, and sweet potato; and (3) appearance score are 5-SL for rice and 3$\mathrm{KD}$ for corn, cassava, potato, and sweet potato.

Banana as staple food gave anomaly perception to students based on its taste and appearance score. Banana's taste score as staple food get the similar score between 4-SR and 5-SL but its appearance score get the similar score between 3-KD and 4-SR. That condition shows that students like the taste of banana as staple food more than the taste of corn, cassava, potato and sweet potato and similar to the taste of rice but students like its appearance similar to the appearance of corn, cassava, potato and sweet potato and less than the appearance of rice.

Formal secondary high education need to work synergize with Indonesian local government in socializing the important and urgency of consuming food diversity, especially staple food as the source of energy intake, to lead the balance eating and mental health of students. The creative and eye-catching socialization will be better in developing students' awareness of food diversity consumption. This awareness will encourage students to eat more diverse food in their family and when they are hanging out with friends. Simanjuntak [19] states that developing awareness of healthy eating through education can be done by socializing the diverse local products eating as sustainable consumption and food security promotion. 


\section{Declaration of Conflicting Interests}

The author declared no potential conflicts of interest with respect to the research, authorship, and/or publication of this article.

\section{ACKNOWLEDGMENT}

The author gets financial support from Christian University of Indonesia for the research and/or authorship of this article.

\section{REFERENCES}

[1] Scaglioni S, M. Salvioni, and C. Galimberti. "Influence of parental attitudes in the development of children eating behavior". Br. J. Nutr. 99: 1,2008 , pp. $2-5$.

[2] Ventura A. K., and L. L. Birch. "Does parenting affect children's eating and weight status?" Int. J. Behav. Nutr. Phys. Act. Vol. 5, 2008, pp. 15 $-27$.

[3] Savage J. S., J. O. Fisher, and L. L. Birch. "Parental influence on eating behavior: conception to adolescence". J. Law. Med. Ethics Vol. 35, 2007, pp $22-34$

[4] Amos, P., Intiful, F., and Boateng, L. "Factors that were found to influence Ghanaian adolescents' eating habits". SAGE Open. December 2012, pp. 1 - 6. Retrieved from http://sgo.sagepub.com/content/2/4/2158244012468140

[5] French, S., et.al. "Cognitive and demographic correlates of low fat vending snack choices among adolescent and adults". Journal of the American Dietetic Association Vol. 99, 1999, pp. 471 - 475.

[6] Koivisto, H. "Factors influencing children's food choice". Annals of Medicine 31:1, 1999. Pp. 26-32

[7] Hoglund, D., Samuelson, G., \& Mark, A. "Food habits in Swedish adolescents in relation to socioeconomic conditions". European Journal of Clinical Nutrition Vol. 52, 1998. Pp. $784-789$.
[8] Rodriguez, C. J. "Eating habits: Nutrition and wellbeing A-Z". 2009. Retrieved from http://www.faqs.org/nutrition/Diab-Em/EatingHabits.html.

[9] Pereira - Santos, M., et.al. "Dietary pattern among nutrition students at a public university in Brazil". Rev. Chil. Nutr. Vol. 43 No. 1, 2016, pp. $39-44$.

[10] Astrup, A. "Carbohydrate as macronutrients in relation to protein and fat for body weight control". International Journal of Obesity Vol. 30, 2006 , pp. $54-59$.

[11] Gahar dan Dadang. "Negara ini memiliki 77 jenis karbohidrat yang berpotensi sebagai sumber pangan". Diakses dari www.revolusinews.com pada tanggal 26 Nopember 2014.

[12] Dalky, H. F., et.al. "Eating habits and associated factors among adolescent students in Jordan". Clinical Nursing Research, May 2016, pp. 1 - 15. Retrieved from cnr.sagepub.com

[13] Suhardjo. Pangan, Gizi dan Pertanian. Jakarta: Universitas Indonesia, 2006.

[14] Ganasegeran, K., et.al. "Social and psychological factors affecting eating habits among university students in a Malaysian medical school: A cross-sectional study". Nutrition Journal, 11:48, 2012, pp. 1-7. Retrieved from http://www.nutritionj.com/content/11/1/48

[15] O'Neil, A., et.al. "Relationship between diet and mental health in children and adolescents: A systematic review". American Journal of Public Health Vol. 104 No. 10, October 2014, pp. e31 - e42.

[16] Moersintowarti. Bahan Ajar II Tumbuh Kembang Anak Remaja. Jakarta: Sagung Seto, 2008

[17] Oddy, W. H., et.al. "The association between dietary patterns and mental health in early adolescent". Preventive Medicine Vol. 49, 2009, pp. $39-44$.

[18] Portland State University. "How diet and nutrition affect mental health". Focal Point: Youth, Young Adults, and Mental Health, Healthy Body - Healthy Mind. Regional Research Institute for Human Services Vol 26 No. 1, 2012, pp. $15-17$.

[19] Simanjuntak, F. N. "Pendidikan kimia bahan makanan untuk membangun kesadaran makan makanan sehat". Jurnal Dinamika Pendidikan Vol. 8 No. 1, April 2015, pp $11-18$. 